Dicle Tıp Dergisi / Dicle Med J (2019) 46 (1) : 109 - 118

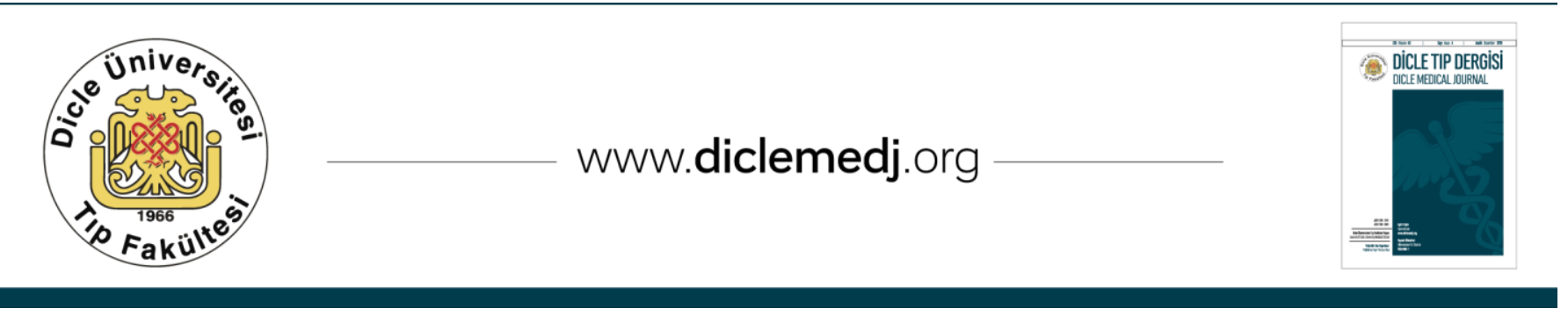

Original Article / Özgün Araştırma

\title{
Arterial Thrombosis Secondary to Cardiac Catheterization in Neonates
}

\author{
Sara Erol'1, Banu Aydın², Hasibe Gokce Cinar ${ }^{3}$, Tamer Yoldas' ${ }^{4}$ Aysegul Zenciroglu ${ }^{5}$ \\ 1 Ylldırım Beyazit University, Faculty of Medicine Department of Neonatology 06010, Bilkent, Ankara, Turkey ORCID: 0000-0002-8758-7662 \\ 2 Lokman Hekim University Faculty of Medicine, Department of Neonatology Çankaya/Ankara, Turkey ORCID: 0000-0002-8677-6090 \\ 3 Department of Radiology, Health Sciences University Ankara Dr. Sami Ulus Maternity and Children Training \& Research Hospital, Altındağ / Ankara, \\ Turkey ORCID:0000-0003-2687-1544 \\ 4 Department of Pediatric Cardiology, Health Sciences University Dr. Sami Ulus Maternity and Children Training \& Research Hospital, Ankara, Turkey \\ ORCID: 0000-0002-5086-6625 \\ 5 Department of Pediatric Neonatology, Health Sciences University Dr. Sami Ulus Maternity and Children Training \& Research Hospital, Ankara, Turkey \\ ORCID: 0000-0002-3488-4962
}

Received: 05.10.2018; Revised: 24.01.2019; Accepted: 29.01.2019

\begin{abstract}
Objective: Cardiac catheterization is one of the basic procedures applied in the diagnosis and treatment of cardiovascular diseases. Development of thrombosis is a serious complication of catheterization. In this study, the frequency and the factors affecting the development of arterial thrombosis were prospectively evaluated in neonates who were subjected to diagnostic or interventional cardiac catheterization.

Methods: Twenty newborns that received femoral artery catheterization within 6-month period were enrolled in this study. Blood samples were taken for complete blood count, prothrombin, activated partial thromboplastin time, INR ratio and mutations of factorV Leiden, prothrombin 20210A, methylenetetrahydrofolate reductase C667T and A1298 before the procedure. $100 \mathrm{U} / \mathrm{kg}$ bolus of heparin was infused during catheterization. $28 \mathrm{U} / \mathrm{kg} / \mathrm{hour}$ infusion of heparin was given to the patients with clinically suspected thrombosis during first few hours after catheterization. Doppler ultrasonography was performed in all patients within 6 hours after catheterization.

Results: The gestational age of patients ranged from 31 to 40 weeks (median 39). Mean birth weight was $2996 \pm 589$ (1880-4000 gr). Arterial thrombosis was detected in 10 patients by Doppler USG. On development of arterial thrombosis, patient age, gender, diagnosis, treatments, platelet count, hemoglobin, prothrombin and activated partial thromboplastin time values, FactorV Leiden, prothrombin 20210A, methylenetetrahydrofolate reductase C667T and A1298 mutations were found as not impacting ( $p>0.05)$. Those who were found to have thrombosis in Doppler ultrasonography had lower INR levels compared to others $(\mathrm{p}=0.023)$.
\end{abstract}

DOI: 10.5798/dicletip.534847

Yazışma Adresi / Correspondence: Sara Erol, Ylldırım Beyazıt University, Faculty of MedicineDepartment of Neonatology 06010, Bilkent Ankara,

Turkeye-mail: sarasurmeli@gmail.com 
Conclusions: The rate of femoral arterial thrombosis in newborns after catheterization detected by Doppler ultrasonography was $50 \%$ in this study. Our data suggest that early clinical assessment for the diagnosis of thrombosis may be misleading but Doppler ultrasonography may be helpful early detection. Further studies are needed to prediction appropriate drugs and/or doses for prevention of thrombosis after arterial catheterization in newborns.

Keywords: newborn, thrombosis, cardiac catheterization

\section{Yenidoğanlarda Kardiyak Kateterizasyona İkincil ArteriyelTromboz}

\section{Öz}

Amaç: Kardiyak kateterizasyon, kardiyovasküler hastalıkların tanı ve tedavisinde kullanılan temel işlemlerden biridir. Tromboz gelişimi, kateterizasyonun ciddi bir komplikasyonudur. Bu çalışmada, tanısal ya da girişimsel amaçlı kardiyak kateterizasyon işlemi yapılan yenidoğanlarda arteriyel tromboz gelişimi sıklığı ve tromboz gelişimine etki eden faktörler ileriye dönük olarak incelendi.

Yöntemler: 6 aylık süreçte femoral arter kateterizasyonu yapılan 20 yenidoğan çalışmaya alındı. İşlem öncesinde tam kan sayımı, prothrombin ve aktive parsiyel tromboplastin zamanları, INR oranı, Faktör V Leiden, protrombin $20210 \mathrm{~A}$, metilentetrahidrofolat redüktaz C667T ve A1298 mutasyonları için kan örnekleri alındı. İșlem sırasında 100 U/ kg dozunda bolus heparin infüzyonu yapıldı. Kateterizasyon sonrasında klinik olarak tromboz şüphesi bulunan hastalara $28 \mathrm{U} / \mathrm{kg} / \mathrm{saat}$ dozunda heparin infüzyonu başlandı. Tüm hastalara kateterizasyon sonrası 6 saat içinde Doopler ultrasonografi yapıldı.

Sonuçlar: Hastaların gestasyonel yaşları 31-40 hafta (ortanca 39 hafta) aralığındaydı. Ortalama doğum ağırlığı $2996 \pm$ 589 gramdı (1880-4000 gr). Doopler ultrasonografi ile 10 hastada arteriyel tromboz saptandı. Arteriyel tromboz gelişimi üzerine hasta yaşının, cinsiyetinin, tanı ve tedavilerin, platelet sayısının, hemoglobin, protrombin ve aktive parsiyel tromboplastin zamanı değerlerinin, Faktör V Leiden, protrombin $20210 \mathrm{~A}$, metilentetrahidrofolat redüktaz C667T ve A1298 mutasyonlarının etkili olmadığı görüldü ( $p>0.05)$. Tromboz saptanan hastaların INR değerleri diğerlerinden daha düşük bulundu ( $\mathrm{p}=0.023)$.

Sonuç: $\mathrm{Bu}$ çalışmada kateterizasyon sonrası femoral arter tromboz sıklığı Doppler ultrasonografiyle \%50 olarak belirlendi. Bizim çalışmamız tromboz tanısında erken klinik değerlendirmenin yanıltıcı olabileceğini fakat Doppler ultrasonografinin erken tanıda yardımcı olabileceğini öngörmektedir. Yenidoğanda arteryel kateterizasyon sonrası trombozun önlenmesi için uygun ilaçların ve / veya dozların tahmin edilmesi için ileri çalışmalara ihtiyaç vardır.

Anahtar Kelimeler: Yenidoğan, tromboz, kardiyak kateterizasyon.

\section{INTRODUCTION}

Cardiac catheterization is one of the basic methods applied in the diagnosis and treatment of congenital and acquired cardiovascular diseases during childhood ${ }^{1}$. However, the fact that cardiac catheterization is an invasive procedure that requires anesthesia encourages

clinicians to use non-invasive methods ${ }^{2}$. Most of congenital heart diseases are diagnosed through non-invasive methods and are referred to surgery. Cardiac catheterization still proves significant for anatomic and hemodynamic complex lesions, though ${ }^{2}$.
Cardiac catheterization can be applied through arterial or venous access. Development of thrombosis at the site of vascular accesses the most frequently observed complication of cardiac catheterization in children ${ }^{3}$. The mechanisms and structures of catheter related thrombosis are different from non catheter - related thrombosis ${ }^{4}$. There exist some mechanisms proposed in relation to postcatheterization thrombosis such as vasospasm, intimal damage, platelet accumulation ${ }^{5}$.

Thrombosis leads to mortality and morbidity in children with congenital heart diseases ${ }^{6}$. For this reason, prevention, early diagnosis, and 
treatment of thrombosis are one of the priorities in patients that received catheterization. During cardiac catheterization, some centers routinely apply heparin infusion into the artery or the vein that received catheter with pediatric patients ${ }^{7}$. There is little research in literature studying the effects of giving prophylactic systemic heparin during cardiac catheterization on the frequency of thrombosis in newborns ${ }^{8}$.

In this study, which was conducted in a Level III neonatal intensive care unit (NICU), the incidence of thrombosis and factors that influence thrombosis development were studied in newborns that received diagnostic or therapeutic catheterization through femoral artery due to cyanotic congenital heart diseases and were routinely given prophylactic systemic heparin during the procedure.

\section{METHODS}

Data collection and study design: All the newborn patients that received diagnostic or therapeutic femoral artery catheterization within 6-month period in tertiary NICU, at Turkey, were involved in the study. The patients without parental consent, and received both arterial and venous intervention during the procedure were excluded from the study. Procedures were classified as diagnostic and interventional. The patients were closely monitored in terms of vital signs and complications during catheterization. Patients were premedicated with midazolam or fentanyl infusions. Appropriate arterial sheaths and catheters varying from $4 \mathrm{~F}$ were used for catheterization. Heparin was given in a dosage of 100 units/ kg intra-arterially through the side- arm of arterial sheath. During the catheterization, the patient's clotting status was monitored by activated clotting time. Fluoroscopy time was recorded. Skin temperature and arterial pulses of the legs and feet were recorded during and after catheterization for every patient.
All the patients were given Doppler ultrasonography (USG) within 6 hours after the catheterization by a radiologist. Following the catheterization, the patients that differed from the other patients in terms of temperature, color, pulse and capillary filling among lower extremities were considered clinically suspected arterial thrombosis. In the presence of clinically suspected arterial thrombosis 75 units/ kg heparin bolus was started and 28 units/ kg/ hour were maintained until the patients received Doppler USG. Bedside Doppler USG of lower extremity arteries and veins was performed by GE Logic E portable ultrasound following cardiac catheterization. First, luminal patency of the vessels was detected by gray-scale sonography. The location of thrombosis, flow rates and flow patterns were evaluated in patients who detected thrombosis using Doppler USG. Heparin infusion was continued in the patients that were found in Doppler USG to have thrombosis restricting the lumen in superficial and common femoral artery. Those patients who did not have clinical thrombosis signs but were found to have thrombosis in Doppler USG were started with 75 units/ kg bolus of heparin infusion, and continued with 28 units/ kg/ hour. The course of vascular thrombosis was followed through Doppler USG screenings until resolving In patients receiving heparin infusion, systemic anticoagulation was provided with low molecular weight heparin (LMWH) after second day. Blood samples according to the study were drawn prior to catheterization for complete blood count (CBC), prothrombin time (PT), activated partial thromboplastin time (aPTT), factor V Leiden, prothrombin G20210A and methylenetetrahydrofolate reductase (MTHFR) C677T and A1298 mutations analysis. aPTT and anti-factor Xa levels of the patients that received heparin treatment were followed for dose adjustment. Gestational weeks, genders, birth weights, catheterization days, type of congenital heart disease, clinic followups after catheter and their complications were 
all recorded. Legal permit was received from local ethics committee (on 19.06.2012 with 61 decision no), and informed consent was received from the families of the patients involved in the study.

Statistical Analysis: Statistical analyses of the data were performed using SPSS V20.0 for Windows. Shapiro Wilks test was conducted to check the distribution of the variables. In summarizing the data, normally distributed variables (parametric) were presented as mean \pm SD, whereas non-normally distributed variables (nonparametric) were presented as median values. The intergroup comparison of normally distributed variables was performed with student $t$ test, and the non-normally distributed variables with Mann-Whitney U test. Chi-square test was used for intergroup comparisons of nominal variables. When cell counts were less than expected in $2 \times 2$ contingency tables, Fisher's Exact Test was applied, whereas Pearson Chi-Square analysis was used by means of Monte Carlo Simulation in $\mathrm{RxC}$ contingency tables. $\mathrm{P}$ value less than 0.05 was considered statistically significant.

\section{RESULTS}

Totally 26 patients received diagnostic and/or therapeutic femoral artery catheterization within 6-month study period. One patient was excluded due to lack of parental consent, and 5 were excluded since they received both arterial and venous intervention during the procedure and 20 newborns that received femoral artery catheterization within 6-month period were involved in the study. The secondary mortality and major complications such as excessive bleeding requiring blood transfusion and vascular rupture were not observed due to cardiac catheterization. The fluoroscopy time was median 10,5 (8-15) min in diagnostic catheterization and median 15,5 (12-26) min in interventional catheterization $(\mathrm{p}=0,001)$. Eight of the cases (40\%) were female, and 12 of them $(60 \%)$ were male. The gestational age of the patients ranged from 31 to 40 weeks (median 39 weeks). Mean birth weight was $2996 \pm 589$ (1880-4000) gr. Primary diagnoses of the patients were coarctation of aorta $(n=11,55 \%)$, pulmonary atresia $(n=6,30 \%)$, aortic valve anomaly $(\mathrm{n}=2,10 \%)$ and pulmonary stenosis $(n=1,5 \%)$. Cardiac catheterization age of the cases was postnatal median 11 (2-65) days. Fifty five \% of the cases $(\mathrm{n}=11)$ were given heparin infusion after the procedure due to suspected thrombosis in light of clinical findings. When the patients were examined 6 hours later with femoral artery Doppler USG, $50 \%$ of them $(n=10)$ were found to have femoral artery thrombosis. Six of the 11 patients (54.5\%) who were initially given additional heparin infusion due to clinically suspected thrombosis were found to have thrombosis in Doppler USG, whereas 4 of the 9 patients 44.4 (\%) who were not given heparin infusion initially were found to have femoral artery thrombosis in the Doppler USG 6 hours later. No statistically significant relationship was found between giving additional heparin on account of clinically suspected thrombosis initially, and ultrasonographic detection of thrombosis during follow-up [p>0.05, Table 1].

No statistically significant correlation was found between the development of thrombosis and gestational week [Thrombosis (+): median 38.5 (31-40) weeks, Thrombosis (-): median 39 (35-40) weeks], birth weight (Thrombosis $(+)$ : $2926 \pm 556$ gr, Thrombosis (-): 3067 \pm 643 gr),the day postnatal angiography was carried out [Thrombosis (+): median 12 (3-65) days, Thrombosis (-):median 10 (2-40) days] and the fluoroscopy time [Thrombosis (+): median 15 (8-26) min, Thrombosis (-):median 13 (9-16) $\min ](p>0.05)$. 
Table 1: The comparison of the heparin infusion for suspected thrombosis and the presence of radiological thrombosis.

\begin{tabular}{|c|c|c|c|c|c|c|c|c|}
\hline & \multicolumn{6}{|c|}{ Additional heparin infusion for clinically suspected thrombosis } & \multirow{2}{*}{$\mathbf{P}$} \\
\hline & & \multicolumn{2}{|c|}{ No } & \multicolumn{2}{|c|}{ Yes } & \multicolumn{2}{|c|}{ Total } & \\
\hline & & $\mathbf{N}$ & $\%$ & $\mathbf{N}$ & $\%$ & $\mathbf{N}$ & $\%$ & \multirow{4}{*}{1.00} \\
\hline \multirow{3}{*}{ Doppler USG } & Thrombosis $(+)$ & 4 & 44.44 & 6 & 54.55 & 10 & 50 & \\
\hline & Thrombosis (-) & 5 & 55.56 & 5 & 45.45 & 10 & 50 & \\
\hline & Total & 9 & 100 & 11 & 100 & 20 & 100 & \\
\hline
\end{tabular}

Table 2: The relationship between the presence of thrombosis and the medication administered, diagnosis and the cause of cardiac catheterization

\begin{tabular}{|c|c|c|c|c|}
\hline & & \multicolumn{2}{|c|}{ Thrombosis } & \multirow{2}{*}{$\mathbf{P}$} \\
\hline & & Yes n (\%) & No n $(\%)$ & \\
\hline \multirow{2}{*}{ Invasiveventilation } & Yes & $3(30)$ & $5(50)$ & \multirow{2}{*}{0.650} \\
\hline & No & $7(70)$ & $5(50)$ & \\
\hline \multirow{2}{*}{ Diuretics } & Yes & $5(50)$ & $5(50)$ & \multirow{2}{*}{1.00} \\
\hline & No & $5(50)$ & $5(50)$ & \\
\hline \multirow{2}{*}{ Inotrops } & Yes & $7(70)$ & $7(70)$ & \multirow{2}{*}{1.00} \\
\hline & No & $3(30)$ & $3(30)$ & \\
\hline \multirow{2}{*}{ PGE2 } & Yes & $8(80)$ & $6(60)$ & \multirow{2}{*}{0.628} \\
\hline & No & $2(20)$ & $4(40)$ & \\
\hline \multirow{4}{*}{ Diagnosis } & Coarctation of aorta & $6(60)$ & $5(50)$ & \multirow{4}{*}{1.00} \\
\hline & Aorticvalve abnormalities & $1(10)$ & $1(10)$ & \\
\hline & Pulmonary atresia & $3(30)$ & $3(30)$ & \\
\hline & Pulmonary stenosis & 0 & $1(10)$ & \\
\hline \multirow{2}{*}{$\begin{array}{l}\text { Aim of } \\
\text { catheterization }\end{array}$} & Diagnostic & $6(60)$ & $4(40)$ & \multirow{2}{*}{0.656} \\
\hline & Interventional & $4(40)$ & $6(60)$ & \\
\hline \multirow{2}{*}{ Mortality } & Yes & $5(50)$ & $6(60)$ & \multirow{2}{*}{1.00} \\
\hline & No & $5(50)$ & $4(40)$ & \\
\hline
\end{tabular}

When the patients need for ventilatory support was examined, it was observed that 8 patients $40(\%)$ received invasive mechanical ventilation, one (5\%) received non-invasive mechanical ventilation, one $(5 \%)$ received freeflow oxygen treatment, whereas 10 patients did not need any ventilatory support. Ten of the patients received (50\%) diuretic, 6 of them (30\%) inotrope, and 6 of them (30\%) prostaglandin E1 treatment prior to the procedure. No correlation was found between the development of thrombosis and the need for ventilation, and receiving diuretic, inotrope, and prostaglandin E1 treatment $(p>0.05)$ [Table 2].

When the correlation between the development of thrombosis and the reason why cardiac catheterization was conducted was examined, no significant correlation was found between diagnostic and interventional cardiac 
catheterization group in terms of thrombosis development; however, the rate of thrombosis was found higher in diagnostic group [Thrombosis (+): Diagnostic $n=6,60(\%)$, Interventional $\mathrm{n}=4,(40 \%)$; Thrombosis $(-)$ : Diagnostic $n=4$ (40\%), Interventional $n=6$, $(60 \%) ; p=0.655]$.There was no significant correlation between primary diagnosis of the patients and development of thrombosis ( $p>0.05)$ [Table 2].

Blood samples were drawn from all patients prior to catheterization for complete blood count, kidney function tests, protein, albumin and coagulation tests. No significant correlation was found between clinically suspected thrombosis cases and those not suspected after cardiac catheterization in terms of hemoglobin, hematocrit, thrombocyte count, blood urea nitrogen, , albumin and protein levels and PT, aPTT and INR values ( $\mathrm{p}>0.05$ ) [Table 3].

Table 3: The relationship between the presence of thrombosis and blood parameters.

\begin{tabular}{|c|c|c|c|}
\hline & Thron & lbosis & D \\
\hline & Yes & No & \\
\hline $\begin{array}{l}\text { Hemoglobin } \\
\text { (g/dl) }\end{array}$ & $14.66 \pm 3.27$ & $13.48 \pm 2.24$ & 0.45 \\
\hline $\begin{array}{l}\text { Hematocrit } \\
(\%)\end{array}$ & $43.31 \pm 10.04$ & $40.69 \pm 6.62$ & 0.623 \\
\hline $\begin{array}{l}\text { Leucocytes } \\
\left(/ \mathrm{mm}^{3}\right)\end{array}$ & $15759 \pm 7195.27$ & $12066 \pm 4112.29$ & 0.406 \\
\hline $\begin{array}{l}\text { Platelets } \\
\left(/ \mathbf{m m}^{3}\right)\end{array}$ & $313300 \pm 164268.11$ & $230400 \pm 126433.29$ & 0.241 \\
\hline $\begin{array}{l}\text { Blood } \\
\text { ureanitrogen } \\
(\mathrm{mg} / \mathrm{dl})\end{array}$ & $9(2-31)$ & $13(0-79)$ & 0.649 \\
\hline Protein (g/dl) & $5.18 \pm 0.56$ & $4.78 \pm 0.82$ & 0.095 \\
\hline $\begin{array}{l}\text { Albumin } \\
(\mathrm{g} / \mathrm{dl})\end{array}$ & $3.15 \pm 0.54$ & $2.84 \pm 0.56$ & 0.211 \\
\hline aPTT $^{*}(\mathbf{s n})$ & $33.9(23.5-46.7)$ & $36.8(24.8-71.7)$ & 0.273 \\
\hline PT* (sn) & $13.9(12.6-19.6)$ & $18.15(12-34.4)$ & 0.29 \\
\hline INR* $(\%)$ & $0.9(0.5-1.64)$ & $1.44(1-2.9)$ & $\mathbf{0 . 0 2 3}$ \\
\hline
\end{tabular}

*activated partial thromboplastin time (aPTT), prothrombin time (PT), international normalized ratio (INR)

Those who were found to have thrombosis in Doppler ultrasonography had lower INR levels compared to others $(p=0.023)$ [Figure 1]. Roc
Curve analysis was done to determine the cutoff value for INR in the presence of thrombosis. Area under curve (AUC) value was found to be 0.80 ( $p=0.023$, CI 95\%: 0.6-0.9). The cut-off value for INR in determining thrombosis was calculated as 1.21 . The specificity, sensitivity, positive and negative predictive values of low INR levels in determining the presence of thrombosis prior to catheterization were calculated as $60 \%$ [Figure 2].

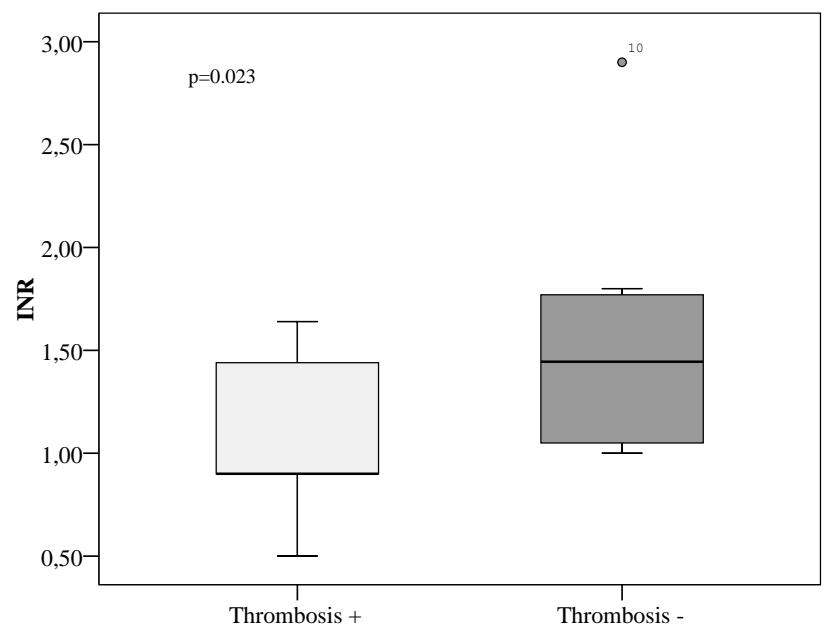

Figure 1: INR levels in patients with and without thrombosis

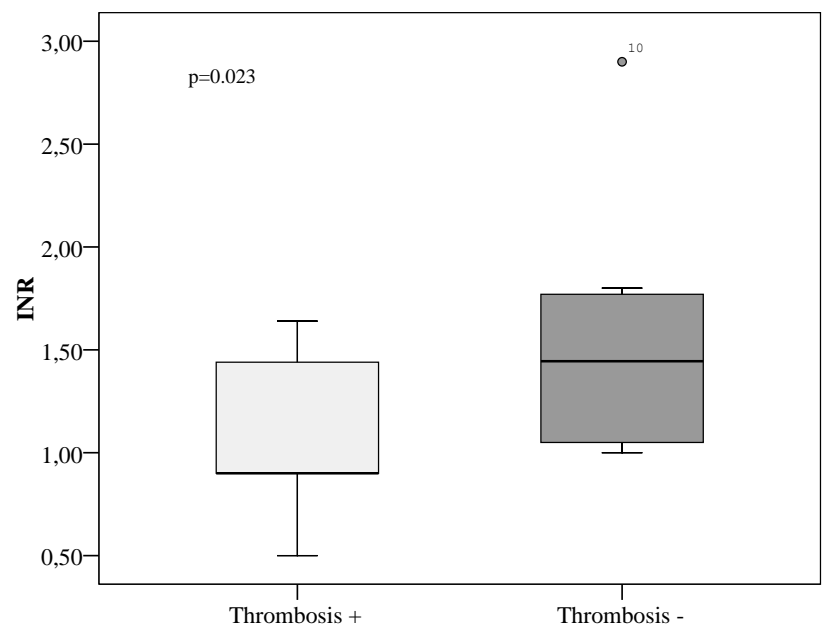

Figure 2: ROC curve analysis for the INR levels 
In 17 of 20 cases, blood samples were taken prior to catheterization for factor $\mathrm{V}$ Leiden, prothrombin G20210A and MTHFR C677T and A1298 mutations. While prothrombin mutations were found to be normal in all the cases with thrombosis, factor $\mathrm{V}$ Leiden mutation was heterozygote in one case (14.5\%). When MTHFR mutations in cases with thrombosis were evaluated, in five cases
MTHR-C677T heterozygote (55.56 \%), in four cases MTHFR-A1298 heterozygote (44.44\%), and in one case MTHFR-A1298 homozygote mutation (11.11\%) were detected. The relationship between the presence of thrombosis and the presence of mutation in these parameters is not statistically significant $(p>0.05)$ [Table 4].

Table 4: The relationship between Thrombosis and Prothrombin 20210 A, Factor V Leiden and MTHFR C677T and A1298 mutations.

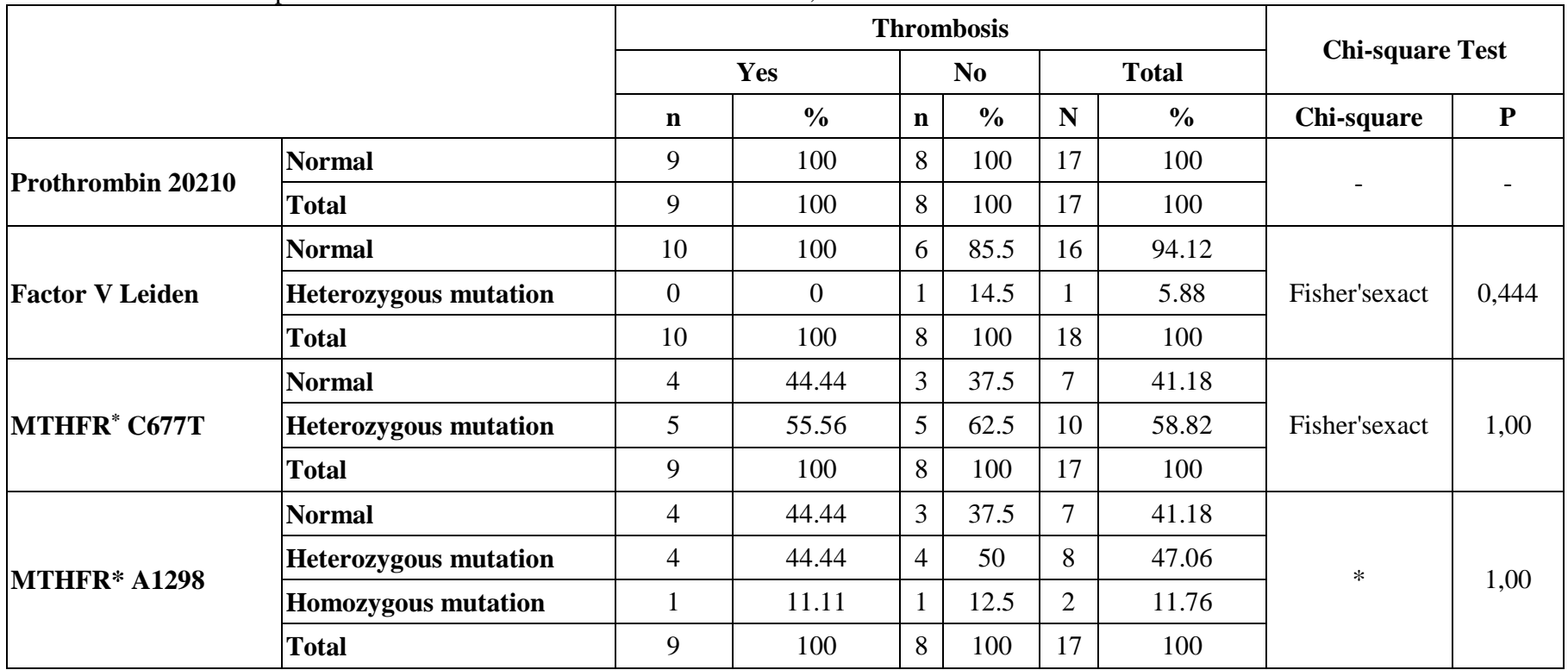

*methylenetetrahydrofolate reductase (MTHFR)

Clinical and Doppler USG findings on thrombosis recovered in all the patients who received heparin treatment due to thrombosis. The patients were discharged from the hospital after the administration of systemic anticoagulant therapy with LMWH treatment. No tissue and function loss was observed in the extremities of the patients none of the patients were given thrombolytic therapy for the treatment of thrombosis.

\section{DISCUSSION}

The technique of percutaneous insertion of catheters, which was developed by Seldinger in $1953^{9}$ was widely used in children in the following years. One major complication of cardiac catheterization in infants and children is the arterial thrombosis. As stated in the literature, the ratio of incidence of femoral venous thrombosis after cardiac catheterization is $0-20 \%$ for infants and children, and the ratio of incidence of femoral arterial thrombosis is $0.8-40 \% 10-16$. In another study, the ratio of incidence of venous thrombosis in cyanotic congenital heart diseases in infants younger than 6 months was found to be $50 \%$, while the ratio of incidence of arterial thrombosis was $70 \%{ }^{17}$. The results of another study show that incidence of femoral arterial thrombosis is $32 \%$ in infants aged $<12$ months ${ }^{18}$. The incidence for newborns is not yet exactly known. In our study, the rate of femoral arterial thrombosis detected by Doppler ultrasonography was $50 \%$. 
Term or preterm infants with a critical illness are at the highest risk in terms of thrombosis development and serious thromboembolic complications in the pediatric population ${ }^{19}$. Major risk factors are fluctuations in cardiac output, congenital heart diseases, inflammation, disseminated intravascular coagulation (DIC), liver dysfunction, and the application of central arterial or venous catheter. As a result of polycythemia and hyper viscosity, developing secondary to the cyanotic congenital heart diseases, blood flow slows down and then thrombosis occurs ${ }^{19}$.The increase in surgical interventions and transcatheter methods leads to an increase in thromboembolism in newborns ${ }^{4}$. The high frequency of arterial thrombosis in our study may be associated with the presence of patients who have congenital heart disease and who received catheterization.

In this study, high thrombosis rate may be associated with the study group consisting of newborns and with the use of Doppler USG for the diagnosis of thrombosis. Brotschi et al. found the incidence of arterial thrombosis after cardiac catheterization as $32 \%$ in infants when they confirmed the diagnosis of thrombosis with Doppler USG ${ }^{18}$.Most studies have only used clinical assessment for the detection of cardiac catheterization related thrombosis and the true incidence of thrombosis is unknown. Therefore, studies using objective screening by ultrasound are needed ${ }^{20}$.In this study, data suggest that clinical assessment for the diagnosis of thrombosis may be misleading.

Prophylactic heparin treatment is a general approach used during cardiac catheterization in children. However, there is not a universallyaccepted heparin dose used to prevent arterial thrombosis. Few studies compare unfractionated heparin (UFH) protocols within the dosage range of 50 to $150 \mathrm{U} / \mathrm{kg}^{10-13}$. The current suggestion is to use 100-150 units per kg body weight bolus UFH and an additional bolus dose during the treatment ${ }^{21}$. In
HEARTCAT study, the superiority of $100 \mathrm{U} / \mathrm{kg}$ UFH dose over $50 \mathrm{U} / \mathrm{kg}$ dose could not be shown. In infants, effects of UFH in plasma were lower than in older children. This age dependency effect of UFH was more noticeable at lower UFH dose 22 . The incidence of thrombosis despite the use of $100 \mathrm{U} / \mathrm{kg} \mathrm{UFH}$ in all the cases in our study may be associated with other factors that may be influential in the development of thrombosis.

Heller and colleagues recommend screening of resistance to activated protein $\mathrm{C}$ (APC-R), protein $\mathrm{C}$, protein $\mathrm{S}$, and antithrombin activity, concentration of clot table fibrinogen, plasminogen activity, activities of coagulation factors VIIIC and XII, Lp(a), histidine-rich glycoprotein, heparin cofactor II, antiphospholipid antibodies, lupus anticoagulants as well as fasting homocysteine concentrations in newborns who developed thromboembolism. In addition, there are studies which suggest performing DNA-based assays (i.e., factor V G1691A mutation, factor II G20210A variant and MTHFR C677T genotype $)^{23,24}$. The presence of some thrombophilia mutations did not shown any effect on the development of thrombosis in this study. This result suggests that environmental factors are particularly effective in acute occlusive situations like arterial thrombosis.

There are several studies showing that children with congenital heart disease have various coagulation disorders ${ }^{25}$. Coagulation factor deficiencies, low platelet, prothrombin time and antithrombin 3 activities were detected in these patients ${ }^{26}$. When the clinical and laboratory parameters which were obtained from our study and which are influential on the development of thrombosis are evaluated, it is seen that the only significant factor is the INR levels. It was found that the cases with thrombosis had lower levels of INR compared to those without thrombosis, and the cut-off value for INR level in detecting thrombosis was found to be 1.21. In patients with an INR 
greater than 1.2, the lower incidence of thrombosis may be due to the more pronounced anticoagulant effect of heparin on these patients. We can speculate according to this result that premedication with effective drugs on INR levels before cardiac catheterization reduces the incidence of thrombosis.

The limitations of our study are low number of patients, heterogenic distribution of gestational ages and birth weights of cases. And also evaluation of clinical findings of thrombosis may show individual differences. The strength of this study is that all patients were closely followed with clinically, laboratory and Doppler USG until discharge.

\section{CONCLUSION}

In recent years, there have been significant improvements in the diagnosis and treatment of congenital heart diseases. Among these recent approaches, preventing the complications resulting from catheterization is one key objective. It is believed that Doppler USG which will be applied on thrombosis before the appearance of secondary clinical findings is important in the early detection and treatment of thrombosis. To prevent thrombotic incidences, new studies must be conducted to explore the heparin bolus doses used during catheterization in newborns. To this end, studies with a large number of cases are required.

\section{Declaration of Conflicting Interests:} Theauthors declare that they have no conflict ofinterest.

Financial Disclosure: No financial supportwas received.

\section{REFERENCES}

1. Glatz AC, Shah SS, McCarthy AL, et all. Prevalence of and risk factors for acute occlusive arterial injury following pediatric cardiac catheterization: a large single-center cohort study. CatheterCardiovascInterv. 2013; 82:454-62.
2. Feltes TF, Bacha E, Beekman RH 3rd, et all; American Heart Association Congenital Cardiac Defects Committee of the Council on Cardiovascular Disease in the Young; Council on Clinical Cardiology; Council on Cardiovascular Radiology and Intervention; American Heart Association. Indications for cardiac catheterization and intervention in pediatric cardiac disease: a scientific statement from the American Heart Association. Circulation. 2011;123:2607-52.

3. Roushdy AM1, Abdelmonem N, El Fiky AA. Factors affecting vascular access complications in children undergoing congenital cardiac catheterization. Cardiol Young. 2012; 22:136-44.

4. Rizzi M, Albisetti M. Treatment of arterial thrombosis in children: Methods and mechanisms. Thromb Res. 2018; 169:113-9.

5. Casa L.D.C, Ku D.N. Thrombus Formation at High Shear Rates. Annu Rev Biomed Eng.2017; 19:415-33.

6. Giglia TM, Massicotte MP, Tweddell JS, et all; American Heart Association Congenital Heart Defects Committee of the Council on Cardiovascular Disease in the Young, Council on Cardiovascular and Stroke Nursing, Council on Epidemiology and Prevention, and Stroke Council. Prevention and treatment of thrombosis in pediatric and congenital heart disease: a scientific statement from the American Heart Association. Circulation. 2013; 128:2622-703.

7. Mortezaiyan H, Aarabi-Moghadam M, Asadpour N, et all. Treatment of femoral artery thrombosis with streptokinase and heparin after cardiac catheterization. Res Cardiovasc Med. 2014;3:e13552.

8. Avila ML, Shah PS, Brandão LR. Different unfractionated heparin doses for preventing arterial thrombosis in children undergoing cardiac catheterization. Cochrane Database Syst Rev. 2014; 3:CD010196.

9. Seldinger SI. Catheter replacement of the needle in percutaneous arteriography; a new technique. Actaradiol. 1953; 39:368-76.

10. Bulbul ZR, Galal MO, Mahmoud E, et all. Arterial complications following cardiac catheterization in children less than $10 \mathrm{~kg}$. Asian CardiovascThorac Ann 2002; 10:129-32.

11. Grady RM, Eisenberg PR, Bridges ND. Rational approach to use of heparin during cardiac catheterization in children. J Am CollCardiol 1995; 25:725-9. 
12. Girod DA, Hurwitz RA, Caldwell RL. Heparinization for prevention of thrombosis following pediatric percutaneous arterial catheterization. PediatrCardiol 1982; 3:175-80.

13. Laurin S, Lundstrom NR. Venous thrombosis after cardiac catheterization in infants. ActaRadiol 1987; 28:241-6.

14. Miga DE, McKellar LF, Denslow S, et all. Incidence of femoral vein occlusion after catheter ablation in children: evaluation with magnetic resonance angiography. PediatrCardiol 1997; 18:204-7.

15. Ruud E, Natvig S, Holmstrom H, Wesenberg F. Low prevalence of femoral venous thrombosis after cardiac catheterizations in children: a prospective study. Cardiol Young 2002; 12:513-8.

16. Keane JF, Lang P, Newburger J, Fyler DC. Iliac veininferior caval thrombosis after cardiac catheterization in infancy. PediatrCardiol 1980; 1:257-61.

17. Monagle P1. Anticoagulation in the young. Heart. 2004; 90:808-12.

18. Brotschi B, Hug M, Kretschmar O, Rizzi M, Albisetti M. Incidence and predictors of cardiac catheterisationrelated arterial thrombosis in children. Heart. 2015;101:948-53.

19. Veldman A, Nold MF, Michel-Behnke I. Thrombosis in the critically ill neonate: incidence, diagnosis, and management. Vasc Health Risk Manag. 2008; 4:133748.
20. Hanslik A, Kitzmüller E, Thom K, et all. Incidence of thrombotic and bleeding complications during cardiac catheterization in children: comparison of high-dose vs. low-dose heparin protocols. J ThrombHaemost. 2011; 9:2353-60.

21. Monagle $\mathrm{P}$, Chalmers E,Chan A, et all. Antithrombotic therapy in children: American College Of Chest Physicians Evidence Based Clinical Practice Guidelines (8th Edition). Chest 2008; 133:887S-968S.

22. Hanslik A, Kitzmüller E, Tran US, et all. Monitoring unfractionated heparin in children: a parallel-cohort randomized controlled trial comparing 2 dose protocols. Blood. 2015 29;126:2091-7.

23. Heller C1, Nowak-Göttl U. Maternal thrombophilia and neonatal thrombosis. Best Pract Res ClinHaematol. 2003; 16:333-45.

24. Kosch A, Kuwertz-Broking E, Heller C, et all. Renal venous thrombosis in neonates: prothrombotic risk factors and long-term followup. Blood 2004;104:135660

25. Ghasemi A, Horri M, Salahshour Y. Coagulation Abnormalities in Pediatric Patients with Congenital Heart Disease: A Literature Review. International Journal of Pediatrics, 2014; 2:141-3.

26. Tempe DK, Viramani S. Coagulation abnormalities in patients with cyanotic congenital heart disease. J CardiothoracVascAnesth 2002; 16:752-65. 